\title{
Deoxypyridinoline to Creatinine Ratio Measurement
}

National Cancer Institute

\section{Source}

National Cancer Institute. Deoxypyridinoline to Creatinine Ratio Measurement. NCI

Thesaurus. Code C79444.

The determination of the ratio of deoxypyridinoline compared to creatinine present in a sample. The measurement may be expressed as a ratio or percentage. 